The beauty of children is beauty's illustration of its constant hunger for new forms, new bodies condensation rising from a rail fence at dawn as if the solid world were melting, as it is.

Every fall is beautiful! The sound of stiff dry leaves skittering down the roof at the wind's brusque urging; high thin sheet of cloud, blues and whites shifting like tropical waters.

October. A spider has dropped a line to my hair.

I am connected to her tiny cave in the tree by a long shining strand. Always eager to be bitten, I turn my head slightly, and both worlds tremble.

\title{
On a Bad Painting In the Lobby of IBM International
}

The sly artist knew what he was doingall color and abstraction, no obsessive rage. I sit with my red leather notebook on my knee, waiting to enter the maze of partitions, to sit and calmly answer charges of substandard service, leveled by a blond manager with a gorgeous tie and bright future. I will not defend the sad imbecilities of my employees but tack the blame on money, how slim the margin of profit, how you get what you pay for, etc, and he'll come back with original agreements, the contract is quite explicit on this point, etc, and we'll shake hands and I'll leave carrying the implied threat of his smile and a list of changes in personnel.

This is only the pattern of little whips I get paid for (same as how many million 
others?), and god knows I no longer blame the pleasant receptionist who must ask three questions one hundred times a day, while she wants only to return to the rating for sexual attraction in Redbook; or the manager doing his best to rise, someday, he trembles to think, to an enclosed office on mahogany row, his service awards and aged brandy hushed and elegant in the glass cabinet; or the ones who believed TV promises and now sit before terminals, pale green light like a sigh on their faces;

or the guys trading numbers in the mailroom, half joking, half praying for the combination that might land them in the local paper, their arm around a woman with an uncertain smile; or even the strong willed ones who descend each noon from glassy clouds, the ones who've learned to say three things at once without anger and appear kind, showing their even teeth-for some are kind, and not one of them unnatural. My client keeps me waiting. I light a third cigarette, check my watch. The painting on the lobby wall is right before me, calm, easy to look at, so little movement inside it is impossible to describe. I touch my forehead and my fingers smear a thin line of moisture. The receptionist is waving.

\section{Looking at a Photograph of my Father at My Age}

The graying brushcut stands up like a warning:

This black and white face is square, lean and dangerous. Seven years out of the FBI and he 